\title{
Article \\ Computational Screening of Metal-Organic Frameworks for Ethylene Purification from Ethane/Ethylene/Acetylene Mixture
}

\author{
Yageng Zhou ${ }^{1}$, Xiang Zhang ${ }^{2}$, Teng Zhou ${ }^{1,2, * \mathbb{C}}$ and Kai Sundmacher ${ }^{1,2}$ \\ 1 Process Systems Engineering, Otto-von-Guericke University Magdeburg, Universitätsplatz 2, \\ D-39106 Magdeburg, Germany; zhouy@mpi-magdeburg.mpg.de (Y.Z.); \\ sundmacher@mpi-magdeburg.mpg.de (K.S.) \\ 2 Process Systems Engineering, Max Planck Institute for Dynamics of Complex Technical Systems, Sandtorstr. 1, \\ D-39106 Magdeburg, Germany; zhangx@mpi-magdeburg.mpg.de \\ * Correspondence: zhout@mpi-magdeburg.mpg.de
}

check for updates

Citation: Zhou, Y.; Zhang, X.; Zhou, T.; Sundmacher, K. Computational Screening of Metal-Organic Frameworks for Ethylene Purification from Ethane/Ethylene/Acetylene Mixture. Nanomaterials 2022, 12, 869. https://doi.org/10.3390/ nano12050869

Academic Editors: Jorge Pasán and Jun Wang

Received: 25 January 2022

Accepted: 2 March 2022

Published: 4 March 2022

Publisher's Note: MDPI stays neutral with regard to jurisdictional claims in published maps and institutional affiliations.

Copyright: () 2022 by the authors. Licensee MDPI, Basel, Switzerland. This article is an open access article distributed under the terms and conditions of the Creative Commons Attribution (CC BY) license (https:// creativecommons.org/licenses/by/ $4.0 /)$.

\begin{abstract}
Identification of high-performing sorbent materials is the key step in developing energyefficient adsorptive separation processes for ethylene production. In this work, a computational screening of metal-organic frameworks (MOFs) for the purification of ethylene from the ternary ethane/ethylene/acetylene mixture under thermodynamic equilibrium conditions is conducted. Modified evaluation metrics are proposed for an efficient description of the performance of MOFs for the ternary mixture separation. Two different separation schemes are proposed and potential MOF adsorbents are identified accordingly. Finally, the relationships between the MOF structural characteristics and its adsorption properties are discussed, which can provide valuable information for optimal MOF design.
\end{abstract}

Keywords: metal-organic framework; gas separation; ethylene purification; $\mathrm{C}_{2}$ hydrocarbons; GCMC simulation; MOF screening

\section{Introduction}

Ethylene $\left(\mathrm{C}_{2} \mathrm{H}_{4}\right)$ is one of the major chemicals in the petroleum industry, which can be produced by thermal cracking from various sources; for instance, natural gas, naphtha, and gasoline [1]. In $\mathrm{C}_{2} \mathrm{H}_{4}$ production, the separations of acetylene $\left(\mathrm{C}_{2} \mathrm{H}_{2}\right)$ and ethane $\left(\mathrm{C}_{2} \mathrm{H}_{6}\right)$ from $\mathrm{C}_{2} \mathrm{H}_{4}$ are achieved through catalytic partial hydrogenation and cryogenic distillation, respectively [2]. However, they are very energy-consuming processes due to extreme operating conditions. Over decades, adsorptive separation under mild conditions on a novel class of nano-porous materials, known as metal-organic frameworks (MOF), has been suggested as a substitute [3]. Due to their structural diversities, MOFs feature many outstanding properties such as tunable pore sizes and high surface areas [4], making them ideal for many applications, such as membranes based purification [5], removal of environmental pharmaceutical contaminants [6,7], gas storage, and in particular gas separation.

A number of MOFs have been reported as promising materials for the separation of $\mathrm{C}_{2} \mathrm{H}_{2} / \mathrm{C}_{2} \mathrm{H}_{4}$ based on different mechanisms. Some utilize a size-selective sieving effect. For example, Xiang et al. discovered that M'MOF-3a could separate $\mathrm{C}_{2} \mathrm{H}_{2}$ and $\mathrm{C}_{2} \mathrm{H}_{4}$ with a high selectivity of 25.53 at $195 \mathrm{~K}$ and 5.23 at $295 \mathrm{~K}$ based on the different sizes of the solutes [8]. Hu et al., (2015) revealed that the suitable pores and opening windows of UTSA-100a could lead to a high $\mathrm{C}_{2} \mathrm{H}_{2}$ uptake of $4.27 \mathrm{mmol} / \mathrm{g}$ and a $\mathrm{C}_{2} \mathrm{H}_{2} / \mathrm{C}_{2} \mathrm{H}_{4}$ selectivity of 10.72 at $296 \mathrm{~K}$ and 1.0 bar. Besides, MOFs featuring open metal sites (OMS) have been found effective for the $\mathrm{C}_{2} \mathrm{H}_{2} / \mathrm{C}_{2} \mathrm{H}_{4}$ separation due to large affinity. However, the OMS bind strongly with both $\mathrm{C}_{2} \mathrm{H}_{2}$ and $\mathrm{C}_{2} \mathrm{H}_{4}$, resulting in a relatively low selectivity. For instance, Bloch et al. demonstrated that $\mathrm{Fe}_{2}$ (dobdc) had a high $\mathrm{C}_{2} \mathrm{H}_{2}$ uptake of $6.8 \mathrm{mmol} / \mathrm{g}$, but a low $\mathrm{C}_{2} \mathrm{H}_{2} / \mathrm{C}_{2} \mathrm{H}_{4}$ selectivity of 2.08 at $318 \mathrm{~K}$ and 1.0 bar [9]. In addition to that, Yang et al. showed that NOTT-300 could separate the mixture through weak supramolecular interactions 
aligned within the host [10]. Finally, MOFs containing anions (such as SIFSIX) have been also found to be promising for $\mathrm{C}_{2} \mathrm{H}_{2} / \mathrm{C}_{2} \mathrm{H}_{4}$ separation [11].

For the separation of $\mathrm{C}_{2} \mathrm{H}_{4} / \mathrm{C}_{2} \mathrm{H}_{6}$, there have been many MOFs reported to be $\mathrm{C}_{2} \mathrm{H}_{4}$ selective, such as $\mathrm{Fe}_{2}$ (dobdc) [9], PAF-1-SO $\mathrm{Ag}$ [12], NOTT-300 [10] etc. However, only limited MOFs with reverse selectivities towards $\mathrm{C}_{2} \mathrm{H}_{6}$ have been reported. Gücüyener et al. first demonstrated the $\mathrm{C}_{2} \mathrm{H}_{6}$ selectivity of ZIF-7 and concluded that its selectivity was induced by a gate-opening mechanism [13]. Liao et al. found that MAF-49 had a $\mathrm{C}_{2} \mathrm{H}_{6}$ selectivity of 2.7 and a capacity of $1.73 \mathrm{mmol} / \mathrm{g}$ at $298 \mathrm{~K}$ [14]. Later, Lin et al. studied $\mathrm{Cu}(\mathrm{Qc})_{2}$ and found that its capacity towards $\mathrm{C}_{2} \mathrm{H}_{6}$ was $1.85 \mathrm{mmol} / \mathrm{g}$ and the $\mathrm{C}_{2} \mathrm{H}_{6} / \mathrm{C}_{2} \mathrm{H}_{4}$ selectivity was 3.4 at $298 \mathrm{~K}$ and $100 \mathrm{kPa}$ [15]. Chen et al. reported an iron-based MOF PCN-250 as another $\mathrm{C}_{2} \mathrm{H}_{6}$ selective adsorbent. Its adsorption capacity towards $\mathrm{C}_{2} \mathrm{H}_{6}$ and $\mathrm{C}_{2} \mathrm{H}_{4}$ was $5.21 \mathrm{mmol} / \mathrm{g}$ and $4.22 \mathrm{mmol} / \mathrm{g}$ at $298 \mathrm{~K}$ and $100 \mathrm{kPa}$, respectively, and the $\mathrm{C}_{2} \mathrm{H}_{6} / \mathrm{C}_{2} \mathrm{H}_{4}$ selectivity was in the range of $1.9-4.0$ [16].

Unlike the widely investigated binary separations, a direct purification of $\mathrm{C}_{2} \mathrm{H}_{4}$ from the ternary mixture $\mathrm{C}_{2} \mathrm{H}_{2} / \mathrm{C}_{2} \mathrm{H}_{4} / \mathrm{C}_{2} \mathrm{H}_{6}$ has been much less studied. There have been basically two different strategies. Hao et al. synthesized a MOF TJT-100 that can simultaneously trap $\mathrm{C}_{2} \mathrm{H}_{2}$ and $\mathrm{C}_{2} \mathrm{H}_{6}$, thus leading to high selectivities for $\mathrm{C}_{2} \mathrm{H}_{2} / \mathrm{C}_{2} \mathrm{H}_{4}$ of 8.5 and $\mathrm{C}_{2} \mathrm{H}_{6} / \mathrm{C}_{2} \mathrm{H}_{4}$ of 5.75 [17]. Chen et al. purified a four-component mixture $\left(\mathrm{C}_{2} \mathrm{H}_{2} / \mathrm{C}_{2} \mathrm{H}_{4} / \mathrm{C}_{2} \mathrm{H}_{6} / \mathrm{CO}_{2}\right)$ in one column packed with three different MOFs with each capturing one impurity [18]. It is worth noticing that both of these novel approaches, where a direct purification of $\mathrm{C}_{2} \mathrm{H}_{2}$ from the ternary $\mathrm{C}_{2}$ mixture instead of performing two separate binary separations, can yield intensified process configurations with less unit operations.

To identify candidates with great potential in the direct purification of the ternary $\mathrm{C}_{2}$ mixture is a challenging task. Fortunately, the grand canonical Monte Carlo (GCMC) simulation can predict adsorption equilibria fast and efficiently. In fact, it has been tested and proven useful in various gas separations, such as $\mathrm{CO}_{2} / \mathrm{N}_{2} / \mathrm{CH}_{4}$ [19-21], $\mathrm{H}_{2} / \mathrm{CH}_{4}$ [22,23], $\mathrm{C}_{2} \mathrm{H}_{2} / \mathrm{CH}_{4}$ and $\mathrm{C}_{2} \mathrm{H}_{2} / \mathrm{CO}_{2}$ [24], $\mathrm{C}_{2} \mathrm{H}_{6} / \mathrm{C}_{2} \mathrm{H}_{4}$ and $\mathrm{C}_{2} \mathrm{H}_{6} / \mathrm{CH}_{4}$ [25], $\mathrm{C}_{2} \mathrm{H}_{2} / \mathrm{C}_{2} \mathrm{H}_{4}$ [26], $\mathrm{CO}_{2} / \mathrm{H}_{2}$ [27], $\mathrm{C}_{3} \mathrm{H}_{8} / \mathrm{C}_{3} \mathrm{H}_{6}$ [28], hexane and heptane isomers [29], xylene isomers [30], and process-centric $\mathrm{CO}_{2}$ capture [31,32].

In this work, we perform a high-throughput screening over 4764 experimentally synthesized MOFs for the separation of $\mathrm{C}_{2} \mathrm{H}_{2} / \mathrm{C}_{2} \mathrm{H}_{4} / \mathrm{C}_{2} \mathrm{H}_{6}$. First, we validate the accuracy of GCMC simulations by comparing the simulated and experimental uptakes of pure $\mathrm{C}_{2} \mathrm{H}_{2}, \mathrm{C}_{2} \mathrm{H}_{4}$, and $\mathrm{C}_{2} \mathrm{H}_{6}$ in a few MOFs. Next, we compute the separation capacity and selectivity for each candidate. Based on that, a new separation performance index (SPI) is defined and discussed in detail. The best MOFs are selected accordingly and the structural characteristics are revealed.

\section{Computational Details}

\subsection{MOF Database}

The computation-ready, experimental metal-organic framework (CoRE MOF) database [33] containing totally $4764 \mathrm{MOF}$ candidates was chosen as the screen basis due to the following reasons. First, this database consists of a variety of MOF structures, which provide a rich search space for finding promising adsorbents; second, the structures in the database are immediately suitable for molecular simulations without any further modifications; third, each MOF has already been experimentally reported and recorded with a unique Cambridge Structural Database (CSD) code [34] so that the screened materials can be synthesized.

\subsection{Molecular Simulation}

Molecular simulation enables multifaceted investigations of intermolecular and intramolecular phenomena on the microscopic scale by advanced computational algorithms. GCMC simulation, with constant chemical potential, volume, and temperature, but variable number of molecules, has been widely used for studying adsorption equilibrium [35]. In 
this work, we implement GCMC simulations using the software RASPA [36] to estimate the adsorption equilibria of the ternary mixture $\mathrm{C}_{2} \mathrm{H}_{2} / \mathrm{C}_{2} \mathrm{H}_{4} / \mathrm{C}_{2} \mathrm{H}_{6}$ over the $4764 \mathrm{MOFs}$.

For the GCMC simulation, various parameters need to be specified properly. First, general parameters such as Monte Carlo moving probabilities, cut-off radius, cell size, and number of cycles are defined. Here, four types of Monte Carlo moves (i.e., translation, rotation, reinsertion, and swap) are considered. The probabilities of the occurrences of these moves are set equal. In addition, a cut-off radius of $12.0 \AA$ is used. The simulation cell size is expanded to at least $24.0 \AA$ along all the three spatial dimensions and the corresponding periodic boundary conditions are applied. Each simulation is carried out with first 30,000 cycles for equilibration and subsequent 20,000 cycles for production. Additionally, the Peng-Robinson equation of state is used to estimate the gas phase fugacities of species.

Next, to calculate the energy state of the whole system, the following force field equation is used [37].

$$
U=\sum 4 \varepsilon_{i j}\left[\left(\frac{\sigma_{i j}}{r_{i j}}\right)^{12}-\left(\frac{\sigma_{i j}}{r_{i j}}\right)^{6}\right]+\sum \frac{q_{i} q_{j}}{4 \pi \varepsilon_{0} r_{i j}}
$$

where $\varepsilon_{i j}$ is well depth, $\sigma_{i j}$ is collision diameter, $r_{i j}$ is the distance between atoms $i$ and $j, q_{i}$ is the atomic charge of atom $i$, and $\varepsilon_{0}$ is $8.8542 \times 10^{-12}\left(\mathrm{C}^{2} \mathrm{~N}^{-1} \mathrm{~m}^{-2}\right)$. The first term describing Van der Waals interactions is the Lennard-Jones (LJ) potential and the second term representing electrostatic interactions is the columbic potential.

In addition to the force field equation, force field parameters are provided. First, for adsorbate molecules $\left(\mathrm{C}_{2} \mathrm{H}_{2}, \mathrm{C}_{2} \mathrm{H}_{4}\right.$, and $\left.\mathrm{C}_{2} \mathrm{H}_{6}\right)$, the Lennard-Jones (LJ) potential parameters $(\sigma$ and $\varepsilon)$, partial charge $(q)$, and bond length $(l)$ are specified. Table 1 lists all the molecular parameters of the gas components where those of $\mathrm{C}_{2} \mathrm{H}_{2}$ are taken from [38] and those of $\mathrm{C}_{2} \mathrm{H}_{4}$ and $\mathrm{C}_{2} \mathrm{H}_{6}$ are adopted from [39]. Next, for host frameworks, the LJ potential parameters are adopted from the DREIDING force field [40] and those of the missing atoms are taken from the UFF force field [41]. The charges on the MOF atoms are estimated using the EQeq method [42]. MOFs are considered as rigid and thus the interactions between MOF atoms are ignored. The cross LJ parameters are computed using the Lorentz-Berthelot combining rule [41] except those between $\mathrm{Cu}$ of $\mathrm{MOF}$ and $\mathrm{C}$ of $\mathrm{C}_{2} \mathrm{H}_{2}$ that are modified according to [38].

Table 1. Molecular Parameters of $\mathrm{C}_{2} \mathrm{H}_{2}, \mathrm{C}_{2} \mathrm{H}_{4}$, and $\mathrm{C}_{2} \mathrm{H}_{6}$.

\begin{tabular}{cccccc}
\hline & Atoms & $\sigma(\AA)$ & $\varepsilon(\mathbf{K})$ & $\boldsymbol{q}(\mathbf{e})$ & Bond Length $\boldsymbol{l}(\AA)$ \\
\hline $\mathrm{C}_{2} \mathrm{H}_{2}$ & $\mathrm{C}$ in $\mathrm{C}_{2} \mathrm{H}_{2}$ & 3.800 & 57.875 & -0.278 & $1.211(\mathrm{C} \equiv \mathrm{C})$ \\
$\mathrm{C}_{2} \mathrm{H}_{4}$ & $\mathrm{H}$ in $\mathrm{C}_{2} \mathrm{H}_{2}$ & 0 & 0 & 0.278 & $1.071(\mathrm{C}-\mathrm{H})$ \\
$\mathrm{C}_{2} \mathrm{H}_{6}$ & $\mathrm{CH}_{2}\left(\mathrm{sp}^{2}\right)$ & 3.685 & 93.0 & 0 & $1.330(\mathrm{C}=\mathrm{C})$ \\
\hline
\end{tabular}

\section{Results and Discussion}

\subsection{GCMC Validation}

The reliability of GCMC simulations was validated by experimental data. In the literature, the amount of $\mathrm{C}_{2} \mathrm{H}_{2}$ and $\mathrm{C}_{2} \mathrm{H}_{4}$ adsorbed on different MOFs (i.e., MOF-5, ZIF-8, and UTSA-20) has been measured at $298 \mathrm{~K}$ and $10^{5} \mathrm{~Pa}[9,43,44]$. In addition, the adsorption uptakes of $\mathrm{C}_{2} \mathrm{H}_{6}$ on Fe-MOF-74, MOF-505, and UTSA-20 have also been measured at $318 \mathrm{~K}$ and $10^{5} \mathrm{~Pa}$ [43]. Under the same experimental conditions, the pure component uptakes of $\mathrm{C}_{2} \mathrm{H}_{6}$ were simulated and those of $\mathrm{C}_{2} \mathrm{H}_{2}$ and $\mathrm{C}_{2} \mathrm{H}_{4}$ were directly taken from our previous work [26].

The comparison of the GCMC results and experimental data is presented in Figure 1. Clearly, the majority of the data lies close to the parity line, indicating an overall good agreement between experimental and simulated uptakes. However, some MOFs such as 
Mg-MOF-74 and Fe-MOF-74 lie far away from the parity line. This is mainly due to the fact that the M-MOF-74 (where M=Mg, Fe et al.) family contains open metal sites (OMS), which can strongly bind with the adsorbates [45]. In this case, the standard force field parameters are unable to appropriately capture these interactions. For better illustration, we calculated the zero coverage isosteric heat of adsorption $Q_{s t}^{0}$ for the two outliers. Note that the absolute value of $Q_{s t}^{0}$ indicates the strength of the MOF-adsorbate interactions. As shown in Table 2, the two $Q_{s t}^{0}$ derived from molecular simulation are significantly lower than the corresponding experimental values, which demonstrates the lack of accurate force field parameters for the description of coordination interactions between OMS and adsorbates. Some methods such as quantum mechanics (QM) calculations [46,47] have been developed to improve the accuracy of force field parameters. However, the identification of MOFs containing OMS is very laborious and the re-adjustment of force field parameters through rigorous QM calculations is computationally expensive. Therefore, to facilitate the large-scale MOF screening, we adopted the general force field parameters to keep a compromise between simulation precisions and computational cost.

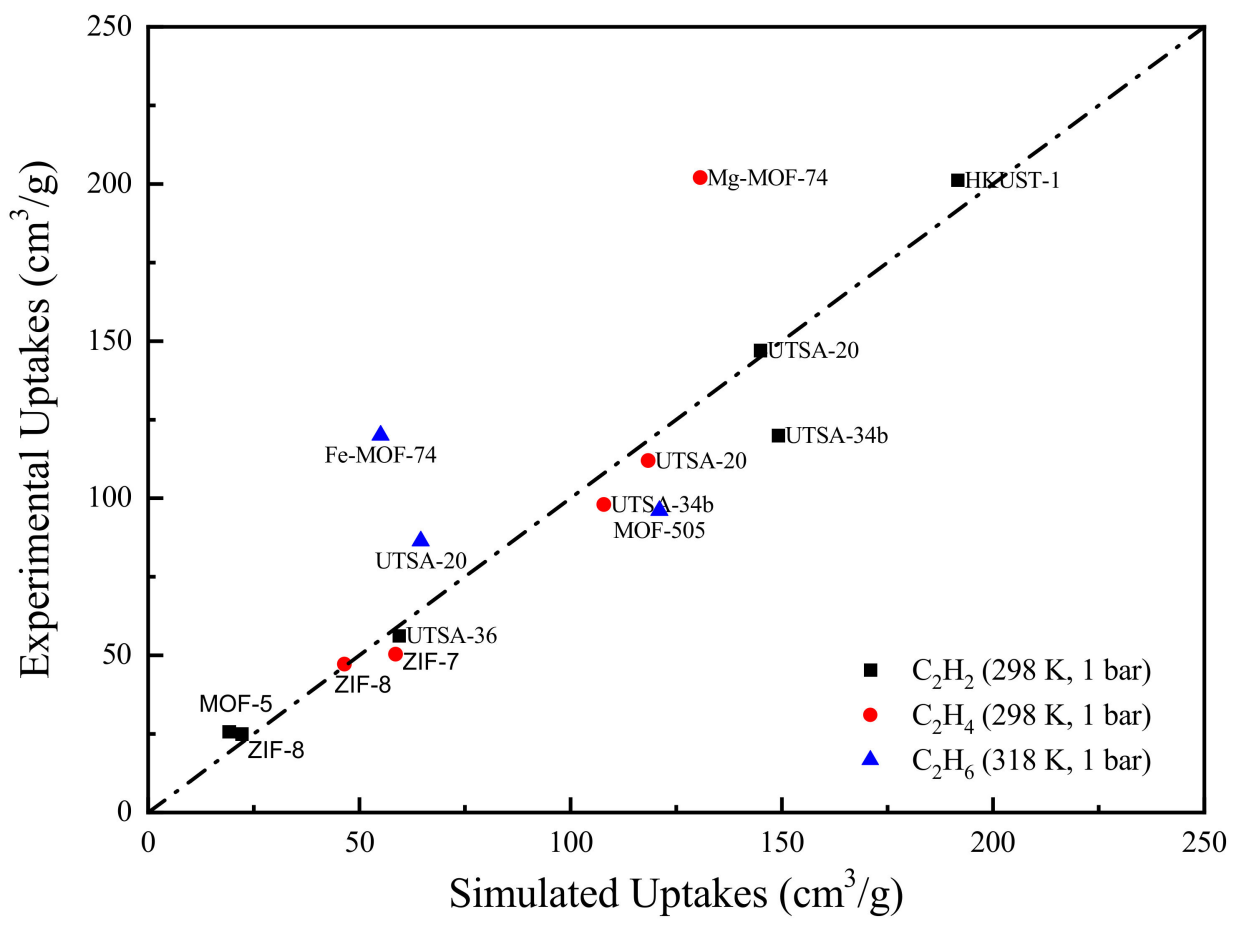

Figure 1. Comparison between experimental and GCMC simulated pure-component adsorption uptakes.

Table 2. Isosteric heat of adsorption at zero coverage $Q_{s t}^{0}$.

\begin{tabular}{ccc}
\hline & Simulated $Q_{s t}^{0}(\mathbf{k J} / \mathbf{m o l})$ & Experimental $Q_{s t}^{0}(\mathbf{k J} / \mathbf{m o l})$ \\
\hline $\mathrm{C}_{2} \mathrm{H}_{6}$ in Fe-MOF-74 at $318 \mathrm{~K}$ & -20.1 & -28.2 \\
$\mathrm{C}_{2} \mathrm{H}_{4}$ in Mg-MOF-74 at $298 \mathrm{~K}$ & -22.8 & -43.0 \\
\hline
\end{tabular}

\subsection{Capacity and Selectivity}

For the evaluation of separation performance of adsorbent, the capacity and selectivity are two important indicators. The adsorption capacity $q_{i}\left(i=\mathrm{C}_{2} \mathrm{H}_{2}, \mathrm{C}_{2} \mathrm{H}_{4}\right.$ and $\left.\mathrm{C}_{2} \mathrm{H}_{6}\right)$ is usually defined as the amount of gas adsorbed in the solid adsorbent. Additionally, the selectivity is typically defined for a binary system (component $=i, j$ ):

$$
S_{i / j}=\frac{K_{i}}{K_{j}}=\frac{x_{i}}{y_{i}} / \frac{x_{j}}{y_{j}}
$$


where $K_{i}$ is the equilibrium constant. $y_{i}$ and $x_{i}$ are the molar fractions of species $i$ in the gas and solid phases, respectively. In a ternary system, selectivity can be defined likewise. For instance, the task of this work is to separate $\mathrm{C}_{2} \mathrm{H}_{2}$ and $\mathrm{C}_{2} \mathrm{H}_{6}$ from the ternary mixture in order to obtain a purified $\mathrm{C}_{2} \mathrm{H}_{4}$ product. Obviously, $\mathrm{MOF}$ with high $\mathrm{C}_{2} \mathrm{H}_{2}$ and $\mathrm{C}_{2} \mathrm{H}_{6}$ uptakes and low $\mathrm{C}_{2} \mathrm{H}_{4}$ uptake are desired. Thus, two selectivity indicators $\left(\mathrm{S}_{\mathrm{C}_{2} \mathrm{H}_{2} / \mathrm{C}_{2} \mathrm{H}_{4}}\right.$ and $S_{\mathrm{C}_{2} \mathrm{H}_{6} / \mathrm{C}_{2} \mathrm{H}_{4}}$ ) can be defined for MOF screening where the first is the selectivity of $\mathrm{C}_{2} \mathrm{H}_{2}$ over $\mathrm{C}_{2} \mathrm{H}_{4}$ and the second is the selectivity of $\mathrm{C}_{2} \mathrm{H}_{6}$ over $\mathrm{C}_{2} \mathrm{H}_{4}$ in the ternary mixture.

We conducted GCMC simulations for all the $4764 \mathrm{MOF}$ in the CoRE MOF database. The concentrations of the three components $\mathrm{C}_{2} \mathrm{H}_{2} / \mathrm{C}_{2} \mathrm{H}_{4} / \mathrm{C}_{2} \mathrm{H}_{6}$ were set to 5.0/90/5.0 $(\mathrm{mol} / \mathrm{mol} / \mathrm{mol})$, and the adsorption simulation was conducted at ambient conditions (i.e., $298 \mathrm{~K}$ and 1.0 bar). Note that only 4462 of the $4764 \mathrm{MOF}$ show valid non-zero uptakes. The obtained equilibrium adsorption loadings of the 4462 MOFs are plotted in Figure 2 with each point representing a single MOF. From this figure, we found that the adsorption uptakes of the three components are roughly in the order of $\mathrm{q}_{\mathrm{C} 2 \mathrm{H} 2}>\mathrm{q}_{\mathrm{C} 2 \mathrm{H} 4}>\mathrm{q}_{\mathrm{C} 2 \mathrm{H} 6}$. This can be explained by the differences in the molecular model parameters. As indicated in Table 1, for both $\mathrm{C}_{2} \mathrm{H}_{6}$ and $\mathrm{C}_{2} \mathrm{H}_{4}$ we used two-site models with three parameters. In contrast, $\mathrm{C}_{2} \mathrm{H}_{2}$ was modeled as a four-site molecule with additional point charge parameters. The introduction of point charges on the $\mathrm{C}$ and $\mathrm{H}$ atoms provides additional electrostatic interactions between $\mathrm{C}_{2} \mathrm{H}_{2}$ and the MOF atoms, which leads to the highest adsorption uptake of $\mathrm{C}_{2} \mathrm{H}_{2}$. Furthermore, a strong correlation between the uptakes of $\mathrm{C}_{2} \mathrm{H}_{4}$ and $\mathrm{C}_{2} \mathrm{H}_{6}$ can be observed from Figure 2. This is primarily due to their similar molecular models and parameters (see Table 1).

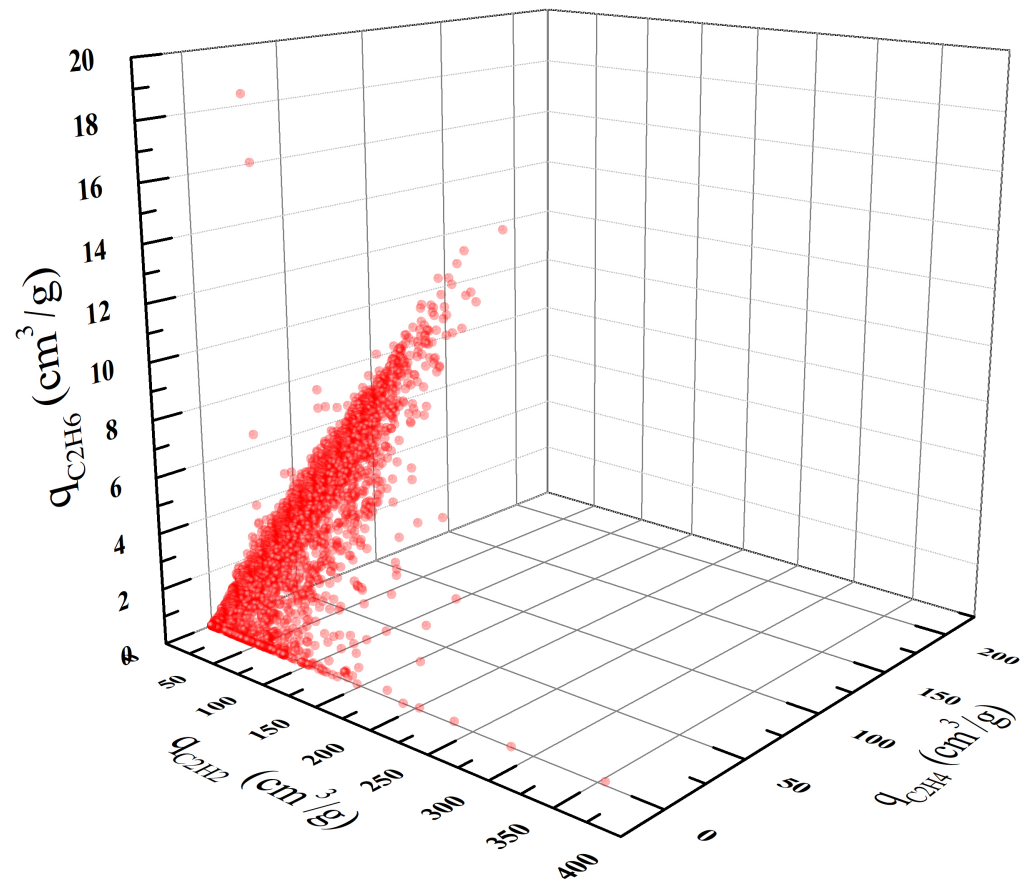

Figure 2. Equilibrium adsorption uptakes of $\mathrm{C}_{2} \mathrm{H}_{2}, \mathrm{C}_{2} \mathrm{H}_{4}$, and $\mathrm{C}_{2} \mathrm{H}_{6}$ in the ternary mixture at $298 \mathrm{~K}$ and 1 bar.

In addition to the adsorption capacity, we calculated the separation selectivity of $\mathrm{C}_{2} \mathrm{H}_{6} / \mathrm{C}_{2} \mathrm{H}_{4}$ and $\mathrm{C}_{2} \mathrm{H}_{2} / \mathrm{C}_{2} \mathrm{H}_{4}$ for each MOF candidate. The results are shown in Figure 3 . It can be found that the selectivity of $\mathrm{C}_{2} \mathrm{H}_{2} / \mathrm{C}_{2} \mathrm{H}_{4}$ spans a wide range. By contrast, the distribution of $\mathrm{C}_{2} \mathrm{H}_{6} / \mathrm{C}_{2} \mathrm{H}_{4}$ selectivity is much narrower. Moreover, most of the $\mathrm{C}_{2} \mathrm{H}_{6} / \mathrm{C}_{2} \mathrm{H}_{4}$ selectivity is lower than 2.0 (red dash line), which reveals the relative difficulty for the separation of $\mathrm{C}_{2} \mathrm{H}_{6}$ from $\mathrm{C}_{2} \mathrm{H}_{4}$. 


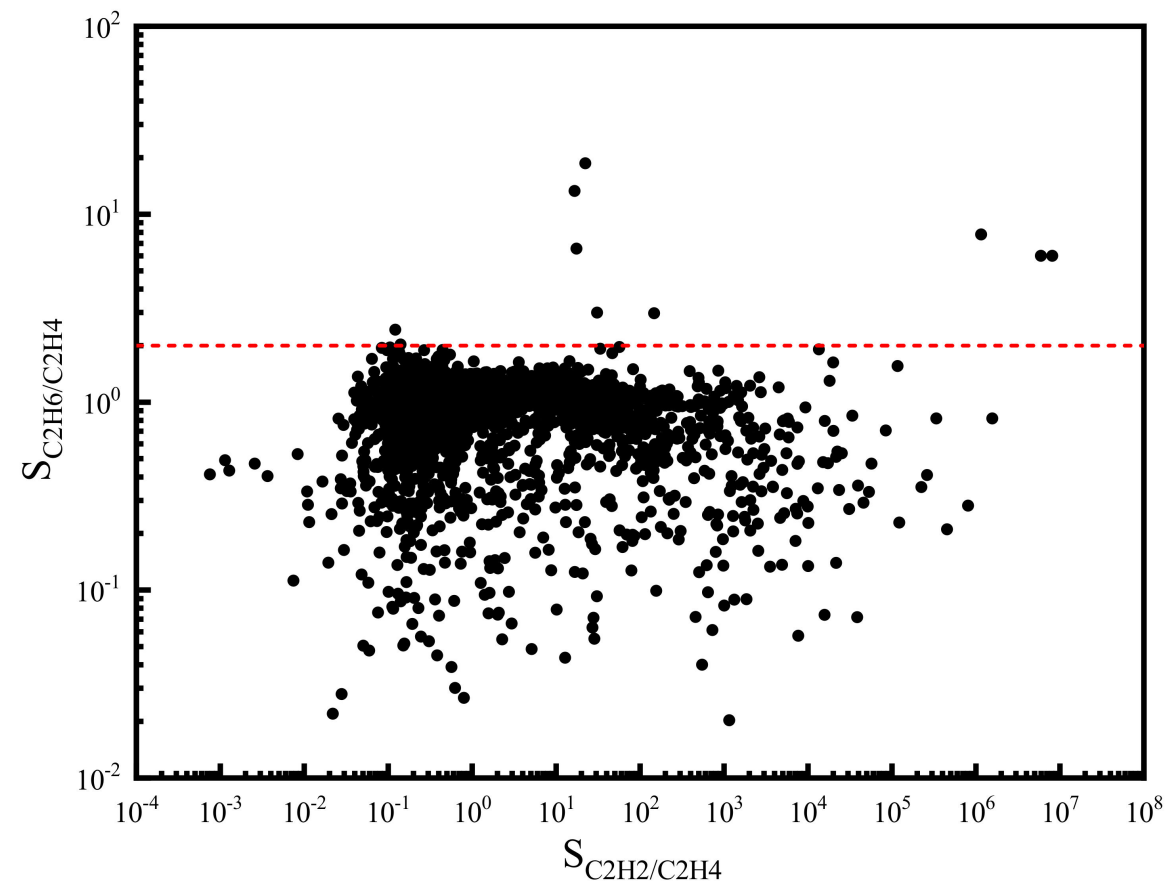

Figure 3. Adsorption selectivity of $\mathrm{C}_{2} \mathrm{H}_{2} / \mathrm{C}_{2} \mathrm{H}_{4}$ and $\mathrm{C}_{2} \mathrm{H}_{6} / \mathrm{C}_{2} \mathrm{H}_{4}$ in the ternary mixture at $298 \mathrm{~K}$ and 1 bar (The red dash line: $\mathrm{S}_{\mathrm{C} 2 \mathrm{H} 6 / \mathrm{C} 2 \mathrm{H} 4}=2.0$ ).

\subsection{Selection of Potential MOFs}

The product of selectivity and capacity has been widely used as a criterion for the selection of MOFs for binary gas separations [24,48]. However, this simple performance indicator needs some modifications before it can be used to rank MOF candidates for ternary separation systems. First, unlike binary systems where a unique pair of selectivity and capacity is involved, for ternary mixtures, selectivity and capacity must be carefully defined to give an appropriate description of the separation performance. Second, the selectivity and capacity often differ in several orders of magnitude. Thus, the direct product of selectivity and capacity can be dominated by one single factor. Such a biased metric is not useful for the screening of best adsorbents. Based on these considerations, we propose a new selection performance indicator (SPI) for the evaluation of the performance of MOFs for the separation of the ternary $\mathrm{C}_{2} \mathrm{H}_{2} / \mathrm{C}_{2} \mathrm{H}_{4} / \mathrm{C}_{2} \mathrm{H}_{6}$ mixture.

$$
\begin{gathered}
S P I=\log \left(S_{\mathrm{C}_{2} \mathrm{H}_{2} / \mathrm{C}_{2} \mathrm{H}_{4}}\right) \times q_{\mathrm{C}_{2} \mathrm{H}_{2}} \times \log \left(S_{\mathrm{C}_{2} \mathrm{H}_{6} / \mathrm{C}_{2} \mathrm{H}_{4}}\right) \times q_{\mathrm{C}_{2} \mathrm{H}_{6}} \\
S P I_{\mathrm{C}_{2} \mathrm{H}_{2}}=\log \left(S_{\mathrm{C}_{2} \mathrm{H}_{2} / \mathrm{C}_{2} \mathrm{H}_{4}}\right) \times q_{\mathrm{C}_{2} \mathrm{H}_{2}} \\
S P I_{\mathrm{C}_{2} \mathrm{H}_{6}}=\log \left(S_{\mathrm{C}_{2} \mathrm{H}_{6} / \mathrm{C}_{2} \mathrm{H}_{4}}\right) \times q_{\mathrm{C}_{2} \mathrm{H}_{6}}
\end{gathered}
$$

To provide a deeper insight of the selection metrics, we divide the SPI into two parts. The product of the first two terms denoted as $S P_{\mathrm{C}_{2} \mathrm{H}_{2}}$ represents the performance of MOF for $\mathrm{C}_{2} \mathrm{H}_{2}$ separation. Similarly, the product of the last two terms denoted as $S P I_{\mathrm{C}_{2} \mathrm{H}_{6}}$ measures MOF's performance for $\mathrm{C}_{2} \mathrm{H}_{6}$ separation. Figure 4 plots the $S P I_{\mathrm{C}_{2} \mathrm{H}_{2}}$ and $S P I_{\mathrm{C}_{2} \mathrm{H}_{6}}$ for all the MOF candidates. It can be observed that $S P I_{\mathrm{C}_{2} \mathrm{H}_{6}}$ is generally much smaller than $S P I_{\mathrm{C}_{2} \mathrm{H}_{2}}$. This confirms that the separation of $\mathrm{C}_{2} \mathrm{H}_{6}$ from $\mathrm{C}_{2} \mathrm{H}_{4}$ is more difficult than the separation of $\mathrm{C}_{2} \mathrm{H}_{2}$ from $\mathrm{C}_{2} \mathrm{H}_{4}$. Moreover, the distribution of $S P I_{\mathrm{C}_{2} \mathrm{H}_{2}}$ and $S P I_{\mathrm{C}_{2} \mathrm{H}_{6}}$ forms a Pareto-like front, which indicates a competitive relation between the separation of $\mathrm{C}_{2} \mathrm{H}_{2}$ and $\mathrm{C}_{2} \mathrm{H}_{6}$. 


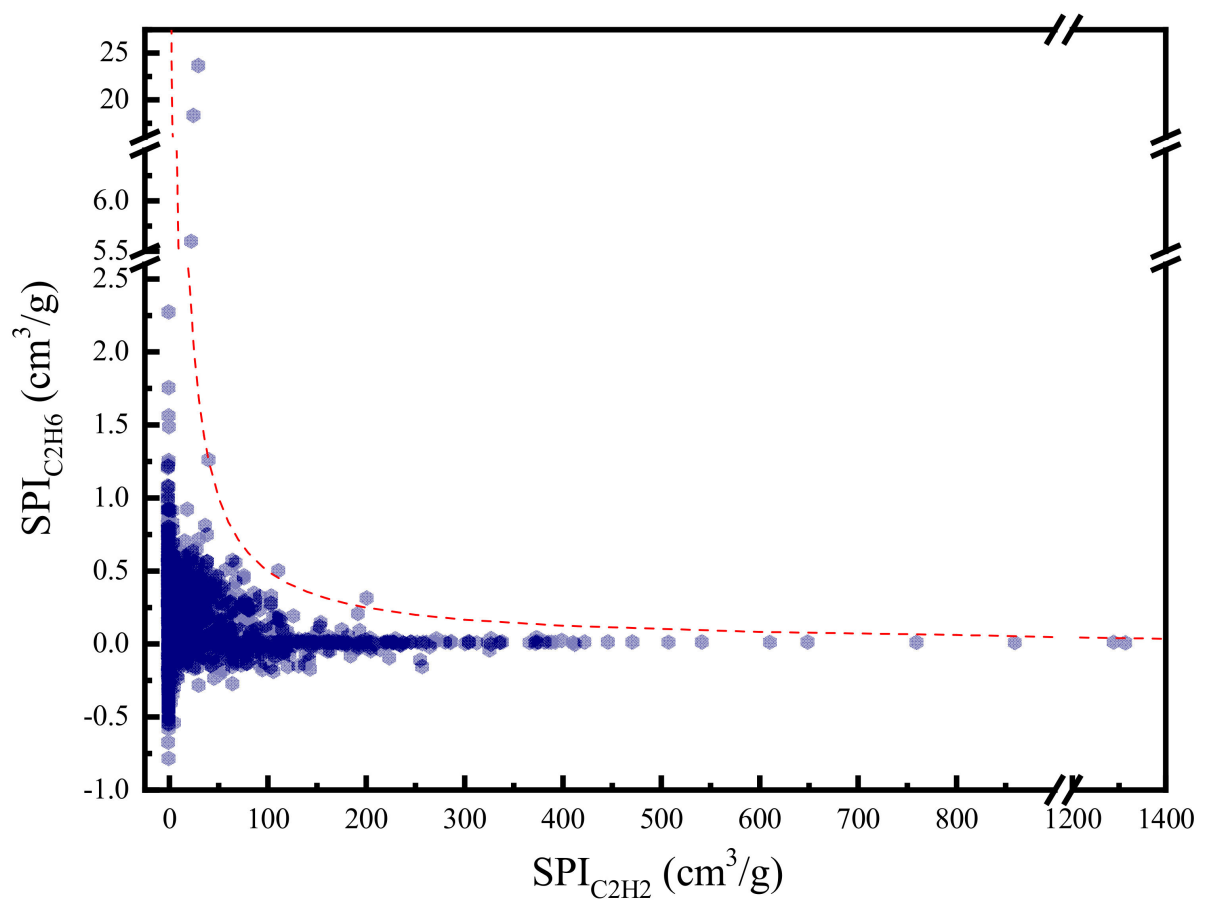

Figure 4. $\mathrm{C}_{2} \mathrm{H}_{2} / \mathrm{C}_{2} \mathrm{H}_{4}$ separation performance versus $\mathrm{C}_{2} \mathrm{H}_{6} / \mathrm{C}_{2} \mathrm{H}_{4}$ separation performance (The red dash line: $\mathrm{SPI}=50$ ).

Two different separation schemes are proposed for the ternary mixture: i.e., singlestep separation and multi-step separation. As illustrated in Figure 5a, in the single-step separation process, $\mathrm{C}_{2} \mathrm{H}_{2}$ and $\mathrm{C}_{2} \mathrm{H}_{6}$ are adsorbed simultaneously in a single sorption cycle and a pure $\mathrm{C}_{2} \mathrm{H}_{4}$ product stream can be obtained directly. This separation process uses only one adsorbent material, which significantly reduces the process complexity. Accordingly, the MOF selection criterion is the maximization of SPI that compromises the material performance for both $\mathrm{C}_{2} \mathrm{H}_{2}$ and $\mathrm{C}_{2} \mathrm{H}_{6}$ separations. Table 3 lists the best 10 MOFs for the single-step separation as well as their corresponding structural properties, selectivity, capacity, and SPI values. As depicted, the most promising MOF is CUNXIS, showing a maximal SPI of $705.8 \mathrm{~cm}^{6} / \mathrm{g}^{2}$.

Table 3. Structural properties, selectivity, capacity, and SPI of the top $10 \mathrm{MOF}$ candidates for the single-step separation of $\mathrm{C}_{2} \mathrm{H}_{2} / \mathrm{C}_{2} \mathrm{H}_{4} / \mathrm{C}_{2} \mathrm{H}_{6}$.

\begin{tabular}{|c|c|c|c|c|c|c|c|c|c|}
\hline Rank & $\begin{array}{l}\text { CSD } \\
\text { Code }\end{array}$ & Metal & $\begin{array}{c}\text { LCD } \\
\text { (̊̊) }\end{array}$ & $\begin{array}{c}\text { Pore } \\
\text { Volume } \\
\left(\mathrm{cm}^{3} / \mathrm{g}\right)\end{array}$ & $S_{C_{2} H_{2} / C_{2} H_{4}}$ & $\begin{array}{c}q_{C_{2} H_{2}} \\
\left(\mathrm{~cm}^{3} / \mathrm{g}\right)\end{array}$ & $S_{C_{2} H_{6} / C_{2} H_{4}}$ & $\begin{array}{c}q_{C_{2} H_{6}} \\
\left(\mathrm{~cm}^{3} / \mathrm{g}\right)\end{array}$ & $\begin{array}{c}\text { SPI } \\
\left(\mathrm{cm}^{6} / \mathrm{g}^{2}\right)\end{array}$ \\
\hline 1 & CUNXIS & $\mathrm{Al}$ & 4.73 & 0.22 & 22.2 & 22.2 & 18.7 & 18.6 & 705.8 \\
\hline 2 & CUNXIS10 & $\mathrm{Al}$ & 4.73 & 0.22 & 16.6 & 20.4 & 13.3 & 16.3 & 455.0 \\
\hline 3 & GIHBII & $\mathrm{Ga}$ & 4.58 & 0.17 & 17.5 & 18.3 & 6.56 & 6.85 & 127.4 \\
\hline 4 & NEXXEV & $\mathrm{Li}$ & 10.14 & 0.92 & 36.7 & 128.8 & 1.18 & 4.15 & 60.8 \\
\hline 5 & JAVTAC & $\mathrm{Al}$ & 5.08 & 0.21 & 147.4 & 51.5 & 2.97 & 1.04 & 54.7 \\
\hline 6 & BEKSAM & $\mathrm{Ga}$ & 4.04 & 0.13 & 30.8 & 27.1 & 2.99 & 2.63 & 50.4 \\
\hline 7 & XEDPON & $\mathrm{Zn}$ & 7.48 & 0.56 & 48.0 & 114.6 & 1.17 & 2.80 & 37.6 \\
\hline 8 & LEVNOQ01 & $\mathrm{Mg}$ & 5.91 & 0.58 & 16.4 & 56.1 & 1.32 & 4.52 & 37.0 \\
\hline 9 & ХЕКСАT01 & $\mathrm{Mg}$ & 5.92 & 0.67 & 11.5 & 61.1 & 1.22 & 6.50 & 36.4 \\
\hline 10 & EYACOX & $\mathrm{Eu}$ & 8.14 & 0.72 & 15.3 & 64.5 & 1.23 & 5.17 & 34.9 \\
\hline
\end{tabular}

Although the single-step process is easy to operate, it may be difficult to find an adsorbent that shows excellent separation performance for both $\mathrm{C}_{2} \mathrm{H}_{2}$ and $\mathrm{C}_{2} \mathrm{H}_{6}$. Additionally, the regeneration of MOF produces a $\mathrm{C}_{2} \mathrm{H}_{6} / \mathrm{C}_{2} \mathrm{H}_{2}$ mixture, which needs to be further 
separated and recycled back to the cracking reactor for maximizing the $\mathrm{C}_{2} \mathrm{H}_{4}$ yield. Considering these factors, another multi-step separation process shown in Figure $5 \mathrm{~b}$ is introduced. Unlike the single-step separation, the multi-step process separates each impurity on an individual adsorbent sequentially. For purifying $\mathrm{C}_{2} \mathrm{H}_{4}$ from $\mathrm{C}_{2} \mathrm{H}_{2} / \mathrm{C}_{2} \mathrm{H}_{4} / \mathrm{C}_{2} \mathrm{H}_{6}$, two different strategies can be employed. Specifically, one can first select a $\mathrm{C}_{2} \mathrm{H}_{2}$-selective MOF to separate $\mathrm{C}_{2} \mathrm{H}_{2}$ and then employ another $\mathrm{C}_{2} \mathrm{H}_{6}$-selective $\mathrm{MOF}$ to adsorb $\mathrm{C}_{2} \mathrm{H}_{6}$. Alternatively, the opposite separation sequence can also be applied. The top five $\mathrm{C}_{2} \mathrm{H}_{2}$-selective MOFs and $\mathrm{C}_{2} \mathrm{H}_{6}$-selective MOFs are listed in Table 4 according to their individual SPI values. The numerous combinations of one adsorbent from each group provide a big chance for the successful implementation of the multi-step separation process. For example, out of all the 25 combinations, ORAQUU and CUNXIS can be selected due to their highest $S P I_{\mathrm{C}_{2} \mathrm{H}_{2}}$ and $S P I_{\mathrm{C}_{2} \mathrm{H}_{6}}$ values.

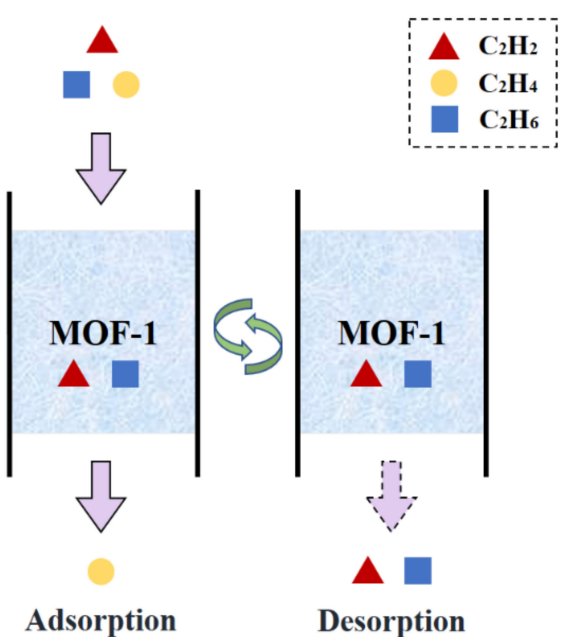

(a)

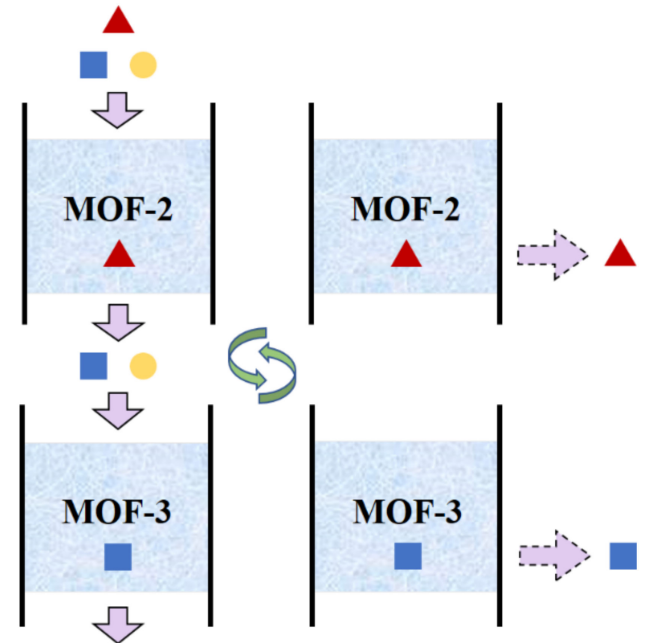

Adsorption
Desorption

(b)

Figure 5. Schematic diagram of two adsorption process configurations for the separation of the $\mathrm{C}_{2} \mathrm{H}_{2} / \mathrm{C}_{2} \mathrm{H}_{4} / \mathrm{C}_{2} \mathrm{H}_{6}$ mixture: (a) single-step separation; (b) multi-step separation.

Table 4. Structural properties, selectivity, capacity, and SPI of the top five MOFs for $\mathrm{C}_{2} \mathrm{H}_{2}$ separation (ranked according to $S P I_{\mathrm{C}_{2} \mathrm{H}_{2}}$ ) as well as the top five MOFs for $\mathrm{C}_{2} \mathrm{H}_{6}$ separation (ranked according to $S P I_{\mathrm{C}_{2} \mathrm{H}_{6}}$ ) for the multi-step separation of $\mathrm{C}_{2} \mathrm{H}_{2} / \mathrm{C}_{2} \mathrm{H}_{4} / \mathrm{C}_{2} \mathrm{H}_{6}$.

\begin{tabular}{|c|c|c|c|c|c|c|c|}
\hline Rank & CSD Code & Metal & LCD (Å) & $\begin{array}{l}\text { Pore Volume } \\
\quad\left(\mathrm{cm}^{3} / \mathrm{g}\right)\end{array}$ & $S_{C_{2} H_{2} / C_{2} H_{4}}$ & $q_{C_{2} H_{2}}\left(\mathrm{~cm}^{3} / \mathrm{g}\right)$ & $S P I_{C_{2} \mathrm{H}_{2}}\left(\mathrm{~cm}^{3} / \mathrm{g}\right)$ \\
\hline 1 & ORAQUU & $\mathrm{Bi}, \mathrm{Zn}$ & 8.39 & 0.68 & 5216.4 & 354.7 & 1318.5 \\
\hline 2 & FENVOL & $\mathrm{Zn}$ & 6.69 & 0.44 & 39528.8 & 281.4 & 1293.7 \\
\hline 3 & ZUQVIQ & Mn & 5.78 & 0.66 & 5033.4 & 232.8 & 861.6 \\
\hline 4 & OHOFEW & Co & 7.31 & 0.68 & 5735.7 & 202.6 & 761.5 \\
\hline 5 & VEHNED & $\mathrm{Na}, \mathrm{Ni}$ & 3.81 & 0.22 & 454736.8 & 115.0 & 650.5 \\
\hline Rank & CSD Code & Metal & LCD (Å) & $\begin{array}{l}\text { Pore Volume } \\
\qquad\left(\mathrm{cm}^{3} / \mathrm{g}\right)\end{array}$ & $S_{C_{2} H_{6} / C_{2} H_{4}}$ & $q_{C_{2} H_{6}}\left(\mathrm{~cm}^{3} / \mathrm{g}\right)$ & $S P I_{C_{2} H_{6}}\left(\mathrm{~cm}^{3} / \mathrm{g}\right)$ \\
\hline 1 & CUNXIS & $\mathrm{Al}$ & 4.73 & 0.22 & 18.7 & 18.6 & 23.6 \\
\hline 2 & CUNXIS10 & $\mathrm{Al}$ & 4.73 & 0.22 & 13.3 & 16.3 & 18.3 \\
\hline 3 & GIHBII & $\mathrm{Ga}$ & 4.58 & 0.17 & 6.56 & 6.85 & 5.6 \\
\hline 4 & UFATEA01 & $\mathrm{Ni}$ & 5.37 & 0.42 & 2.02 & 7.41 & 2.3 \\
\hline 5 & CEYPUT & $\mathrm{Co}$ & 5.37 & 0.42 & 1.82 & 6.71 & 1.7 \\
\hline
\end{tabular}




\subsection{Structure-Property Relationship Study}

Some valuable insights can be extracted from the screening results by conducting the structure-property relationship study. These insights provide useful information for the experimental design of novel high-performing adsorbents. First, to quantify the influence of structural parameters on the adsorption selectivity, the relationship between the largest cavity diameter (LCD) and the selectivity of $\mathrm{C}_{2} \mathrm{H}_{2} / \mathrm{C}_{2} \mathrm{H}_{4}$ and $\mathrm{C}_{2} \mathrm{H}_{6} / \mathrm{C}_{2} \mathrm{H}_{4}$ is shown in Figure 6. As depicted in Figure 6a, the majority of the $\mathrm{C}_{2} \mathrm{H}_{2} / \mathrm{C}_{2} \mathrm{H}_{4}$ selectivity are higher than 1.0 and the highest selectivities are generally achieved at very low LCDs (below $4.0 \AA$ ). When only looking at the data, the $\mathrm{C}_{2} \mathrm{H}_{2} / \mathrm{C}_{2} \mathrm{H}_{4}$ selectivity of which is above 1.0 , the selectivity generally decreases as the LCD increases. Similar trends in relations between LCD and selectivity were reported in the literature [21,49]. In Figure 6b, however, one can see that the selectivity of $\mathrm{C}_{2} \mathrm{H}_{6} / \mathrm{C}_{2} \mathrm{H}_{4}$ increases with LCD and reaches its highest value at around $4.7 \AA$. As the LCD increases further, both selectivities tend to converge to 1.0. This indicates that MOFs with very large LCDs are neither $\mathrm{C}_{2} \mathrm{H}_{2}$-selective nor $\mathrm{C}_{2} \mathrm{H}_{6}$-selective. This is not surprising because when the LCD is small, where three components have to compete for limited adsorption space, molecules with smaller size will be bound more easily. When LCD increases, more adsorption sites become available, hence all the components eventually will have equal chances to be adsorbed on frameworks.

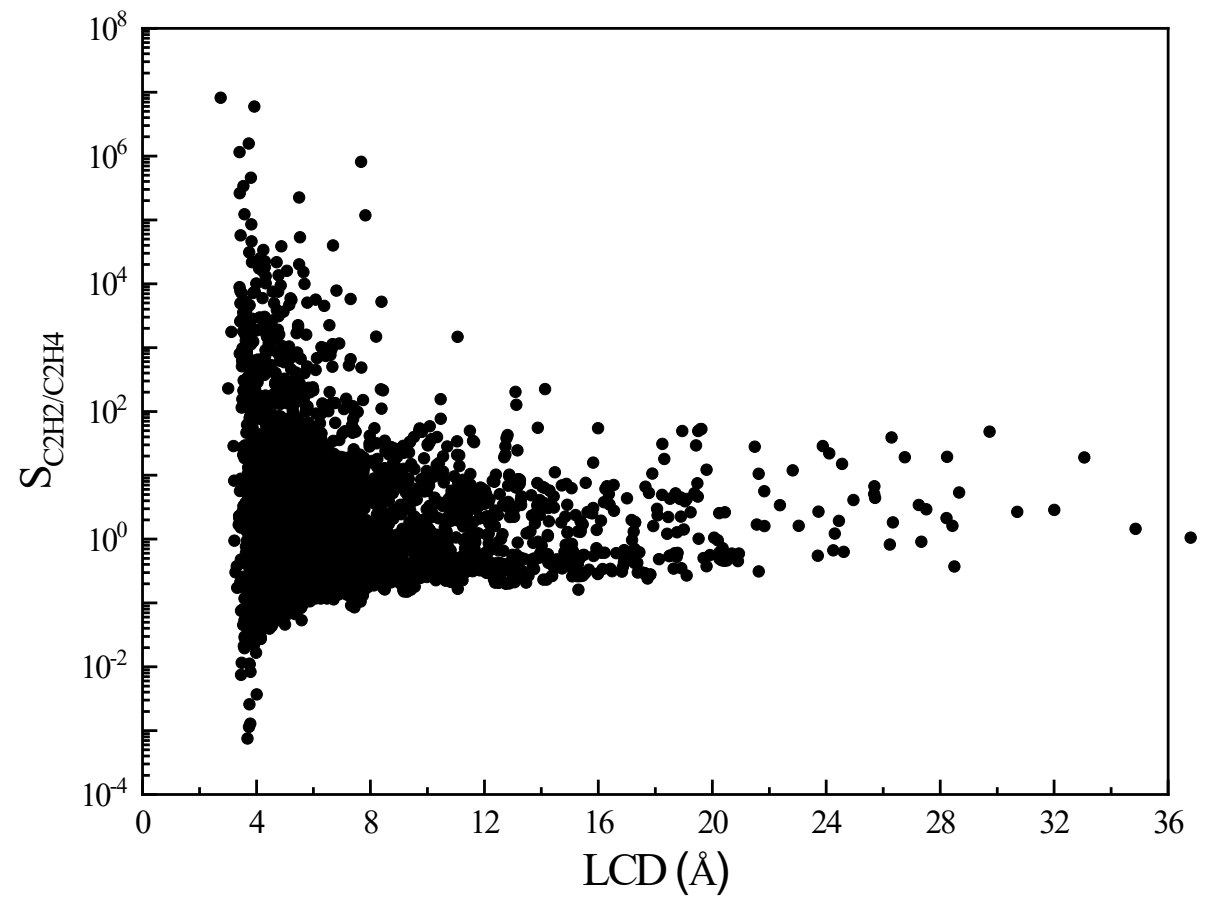

(a)

Figure 6. Cont. 


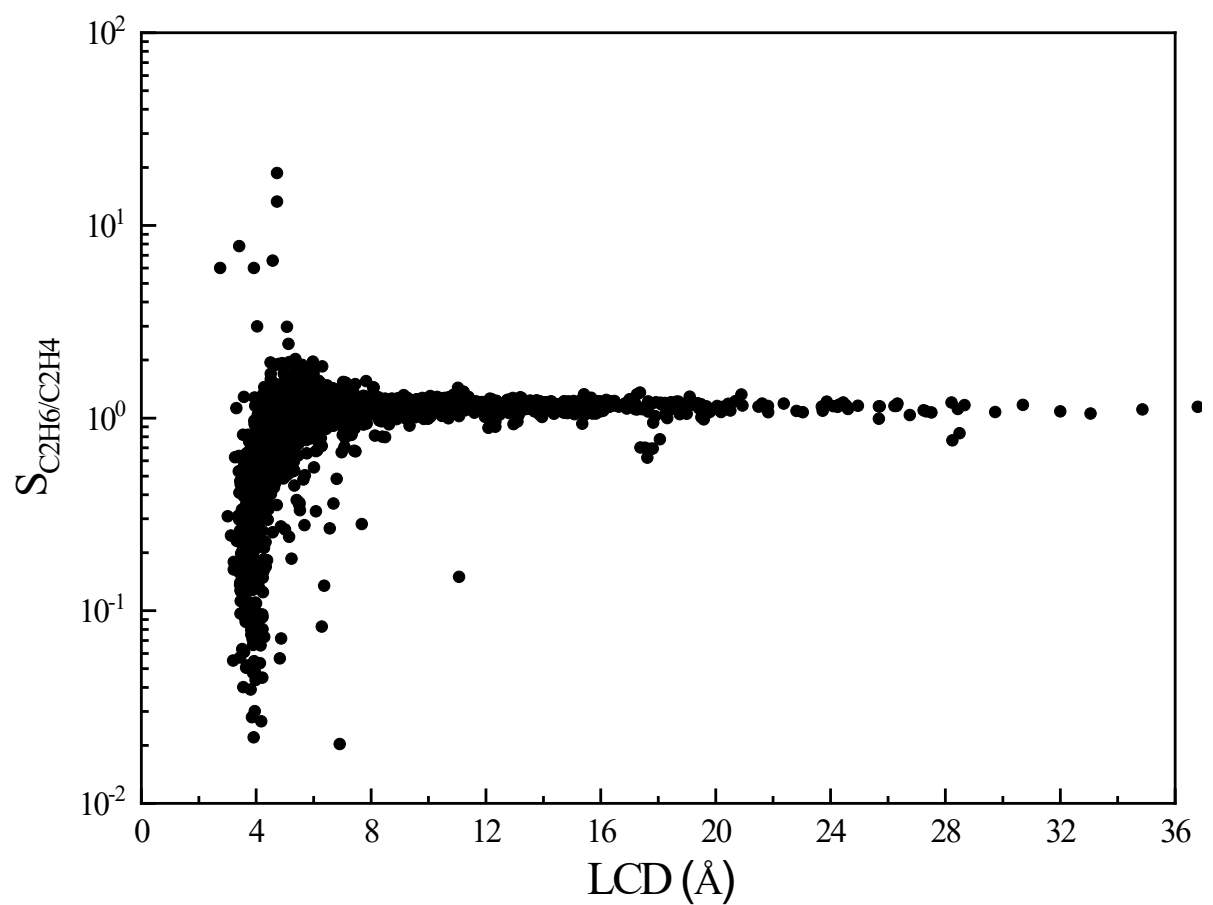

(b)

Figure 6. Adsorption selectivity of MOF with respect to (a) $\mathrm{C}_{2} \mathrm{H}_{2} / \mathrm{C}_{2} \mathrm{H}_{4}$ and (b) $\mathrm{C}_{2} \mathrm{H}_{6} / \mathrm{C}_{2} \mathrm{H}_{4}$ versus LCD.

Figure 7 shows the dependency of adsorption capacity on pore volume of MOF. As indicated in Figure $7 \mathrm{a}$, the adsorption capacity of $\mathrm{C}_{2} \mathrm{H}_{2}$ increases with the pore volume until it achieves a maximal value of $354.7 \mathrm{~cm}^{3} / \mathrm{g}$ at pore volume of $0.68 \mathrm{~cm}^{3} / \mathrm{g}$. As the pore volume increases further, the capacity of $\mathrm{C}_{2} \mathrm{H}_{2}$ starts to decline and finally converges to $2.5 \mathrm{~cm}^{3} / \mathrm{g}$. Figure $7 \mathrm{~b}, \mathrm{c}$ shows a similar trend. Generally, the adsorption capacities of both $\mathrm{C}_{2} \mathrm{H}_{4}$ and $\mathrm{C}_{2} \mathrm{H}_{6}$ increase with pore volume until reaching the peak. Further increasing the pore volume, the adsorption capacities of $\mathrm{C}_{2} \mathrm{H}_{4}$ and $\mathrm{C}_{2} \mathrm{H}_{6}$ gradually decline to a limit value of $25.0 \mathrm{~cm}^{3} / \mathrm{g}$ and $1.5 \mathrm{~cm}^{3} / \mathrm{g}$, respectively. It is observed that high capacities are achieved at moderate pore volumes. This might be explained by the fact that the pore volume is inversely proportional to framework density as demonstrated by Kong et al. [50]. Thus, adsorption capacities are always subjected to a balance between pore volume and MOF density. Comparing Figure $7 \mathrm{a}-\mathrm{c}$, although increasing the pore volume until $0.68 \mathrm{~cm}^{3} / \mathrm{g}$ leads to a larger adsorption capacity of impurities $\mathrm{C}_{2} \mathrm{H}_{2}$ and $\mathrm{C}_{2} \mathrm{H}_{6}$, it also causes a higher loss of product $\mathrm{C}_{2} \mathrm{H}_{4}$. Besides, due to the very analogous dependency of adsorption capacities of $\mathrm{C}_{2} \mathrm{H}_{4}$ and $\mathrm{C}_{2} \mathrm{H}_{6}$ on pore volume, the amount of removed $\mathrm{C}_{2} \mathrm{H}_{6}$ is always proportional to the amount of lost $\mathrm{C}_{2} \mathrm{H}_{4}$. 


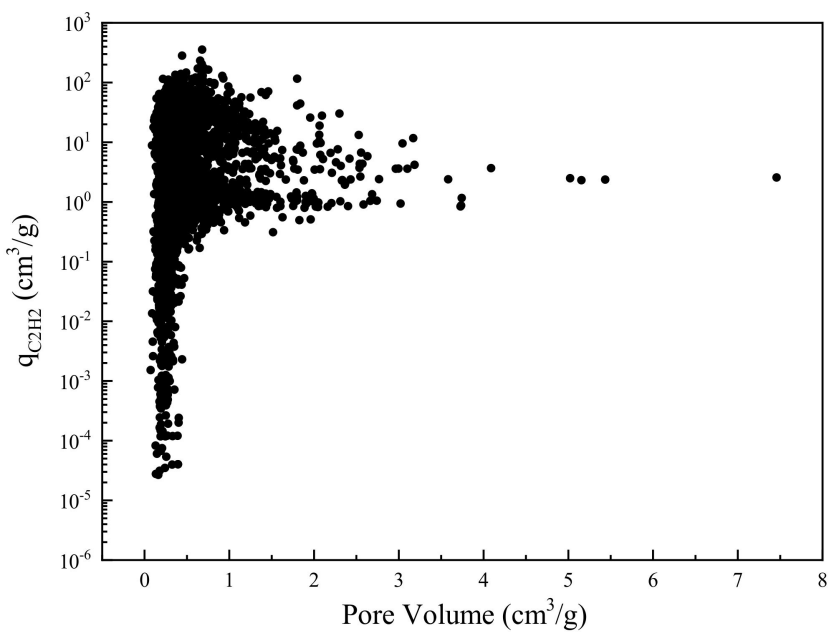

(a)

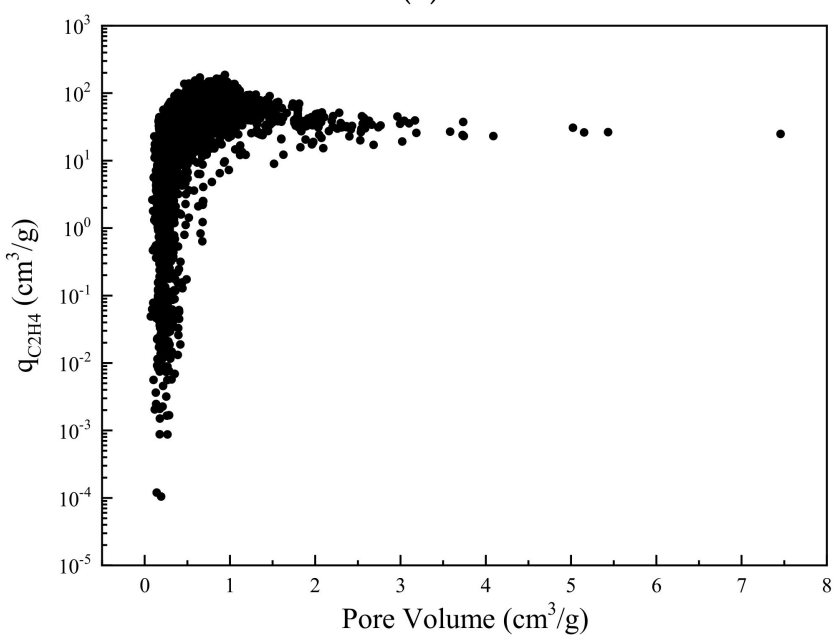

(b)

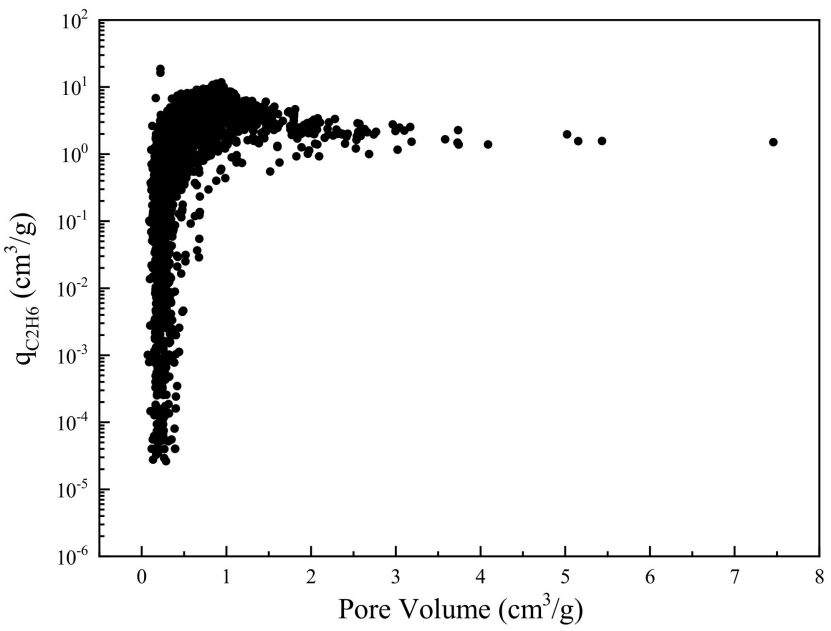

(c)

Figure 7. Adsorption capacity of MOF for (a) $\mathrm{C}_{2} \mathrm{H}_{2}$, (b) $\mathrm{C}_{2} \mathrm{H}_{4}$, and (c) $\mathrm{C}_{2} \mathrm{H}_{6}$ with dependence on pore volume.

\section{Conclusions}

In summary, we studied the separation of $\mathrm{C}_{2} \mathrm{H}_{4}$ from the $\mathrm{C}_{2} \mathrm{H}_{2} / \mathrm{C}_{2} \mathrm{H}_{4} / \mathrm{C}_{2} \mathrm{H}_{6}$ mixture and screened the MOF adsorbents from the CoRE MOF database by GCMC simulation. We first validated its accuracy and showed that the force field in general yielded satisfac- 
tory results for adsorption equilibrium prediction, except for a few MOFs with the OMS effect. Next, new evaluation metrics SPI were proposed for single-step and multi-step separation strategies for $\mathrm{C}_{2}$ ternary mixtures. For single-step separation processes, among all, CUNXIS with the highest SPI value at $705.8 \mathrm{~cm}^{6} / \mathrm{g}^{2}$ was identified as the best. For multi-step separation processes, ORAQUU and CUNXIS with SPI being $1318.5 \mathrm{~cm}^{3} / \mathrm{g}$ and $23.6 \mathrm{~cm}^{3} / \mathrm{g}$, respectively formed the best combination. Finally, we discovered that $\mathrm{S}_{\mathrm{C} 2 \mathrm{H} 2 / \mathrm{C} 2 \mathrm{H} 4}$ decreased with increasing $\mathrm{LCD}$, and $\mathrm{S}_{\mathrm{C} 2 \mathrm{H} 6 / \mathrm{C} 2 \mathrm{H} 4}$ increased with increasing LCD. For all three components, capacities increased first with pore volume until reaching the peak and after that slowly converged.

However, there are two drawbacks of our study. First, we assumed that thermodynamics is the dominant controlling mechanism in our adsorption system, hence kinetics are ignored. Consequently, MOFs that achieved separations by exploiting the differences in diffusion rates of different species were out of the scope of the search. Second, the selection criteria SPI may not necessarily guarantee a success in practical processes, because it is derived from the phase level properties alone. So future studies containing detailed process modelling or experiments can be carried out for improvement.

Author Contributions: Conceptualization, Y.Z. and T.Z.; methodology, T.Z.; software, Y.Z.; validation, Y.Z. and X.Z.; investigation, Y.Z.; resources, K.S.; data curation, Y.Z.; writing-original draft preparation, Y.Z.; writing-review and editing, X.Z., T.Z. and K.S.; supervision, T.Z. and K.S.; project administration, T.Z.; funding acquisition, T.Z. and K.S. All authors have read and agreed to the published version of the manuscript.

Funding: This research was funded by Deutsche Forschungsgemeinschaft (DFG) with grant number SFB/TRR 63 InPROMPT.

Institutional Review Board Statement: Not applicable.

Informed Consent Statement: Not applicable.

Data Availability Statement: Not applicable.

Acknowledgments: This work was conducted in cooperation with the Collaborative Research Center SFB/TRR 63 "Integrated Chemical Processes in Liquid Multiphase Systems (InPROMPT)". The financial support from the Deutsche Forschungsgemeinschaft (DFG) is gratefully acknowledged. Moreover, Teng Zhou acknowledges the financial support from the Max Planck Society, Germany, for his Junior Professorship at the Otto-von-Guericke University Magdeburg dedicated to ComputerAided Material and Process Design (CAMPD).

Conflicts of Interest: The authors declare no conflict of interest.

\section{References}

1. Gao, Y.; Neal, L.; Ding, D.; Wu, W.; Baroi, C.; Gaffney, A.M.; Li, F. Recent Advances in Intensified Ethylene Production-A Review. ACS Catal. 2019, 9, 8592-8621. [CrossRef]

2. Sholl, D.S.; Lively, R.P. Seven chemical separations to change the world. Nature 2016, 532, 435-437. [CrossRef] [PubMed]

3. Li, J.-R.; Kuppler, R.J.; Zhou, H.-C. Selective gas adsorption and separation in metal-organic frameworks. Chem. Soc. Rev. 2009, 38, 1477-1504. [CrossRef] [PubMed]

4. Zhou, H.-C.; Long, J.R.; Yaghi, O.M. Introduction to Metal-Organic Frameworks. Chem. Rev. 2012, 112, 673-674. [CrossRef]

5. Nabeel, F.; Rasheed, T.; Bilal, M.; Li, C.; Yu, C.; Iqbal, H.M.N. Bio-Inspired Supramolecular Membranes: A Pathway to Separation and Purification of Emerging Pollutants. Sep. Purif. Rev. 2020, 49, 20-36. [CrossRef]

6. Rasheed, T.; Ahmad, N.; Ali, J.; Hassan, A.A.; Sher, F.; Rizwan, K.; Iqbal, H.M.N.; Bilal, M. Nano and micro architectured cues as smart materials to mitigate recalcitrant pharmaceutical pollutants from wastewater. Chemosphere 2021, 274, 129785. [CrossRef]

7. Rasheed, T.; Rizwan, K.; Bilal, M.; Sher, F.; Iqbal, H.M.N. Tailored functional materials as robust candidates to mitigate pesticides in aqueous matrices-A review. Chemosphere 2021, 282, 131056. [CrossRef]

8. Xiang, S.-C.; Zhang, Z.; Zhao, C.-G.; Hong, K.; Zhao, X.; Ding, D.-R.; Xie, M.-H.; Wu, C.-D.; Das, M.C.; Gill, R.; et al. Rationally tuned micropores within enantiopure metal-organic frameworks for highly selective separation of acetylene and ethylene. Nat. Commun. 2011, 2, 204. [CrossRef]

9. Bloch, E.D.; Queen, W.L.; Krishna, R.; Zadrozny, J.M.; Brown, C.M.; Long, J.R. Hydrocarbon Separations in a Metal-Organic Framework with Open Iron(II) Coordination Sites. Science 2012, 335, 1606-1610. [CrossRef] 
10. Yang, S.; Ramirez-Cuesta, A.J.; Newby, R.; Garcia-Sakai, V.; Manuel, P.; Callear, S.K.; Campbell, S.I.; Tang, C.C.; Schröder, M. Supramolecular binding and separation of hydrocarbons within a functionalized porous metal-organic framework. Nat. Chem. 2014, 7, 121. [CrossRef]

11. Cui, X.; Chen, K.; Xing, H.; Yang, Q.; Krishna, R.; Bao, Z.; Wu, H.; Zhou, W.; Dong, X.; Han, Y.; et al. Pore chemistry and size control in hybrid porous materials for acetylene capture from ethylene. Science 2016, 353, 141-144. [CrossRef] [PubMed]

12. Li, B.; Zhang, Y.; Krishna, R.; Yao, K.; Han, Y.; Wu, Z.; Ma, D.; Shi, Z.; Pham, T.; Space, B.; et al. Introduction of $\pi$-Complexation into Porous Aromatic Framework for Highly Selective Adsorption of Ethylene over Ethane. J. Am. Chem. Soc. 2014, 136, 8654-8660. [CrossRef] [PubMed]

13. Gücüyener, C.; van den Bergh, J.; Gascon, J.; Kapteijn, F. Ethane/Ethene Separation Turned on Its Head: Selective Ethane Adsorption on the Metal-Organic Framework ZIF-7 through a Gate-Opening Mechanism. J. Am. Chem. Soc. 2010, 132, 17704-17706. [CrossRef] [PubMed]

14. Liao, P.-Q.; Zhang, W.-X.; Zhang, J.-P.; Chen, X.-M. Efficient purification of ethene by an ethane-trapping metal-organic framework. Nat. Commun. 2015, 6, 8697. [CrossRef]

15. Lin, R.-B.; Wu, H.; Li, L.; Tang, X.-L.; Li, Z.; Gao, J.; Cui, H.; Zhou, W.; Chen, B. Boosting Ethane/Ethylene Separation within Isoreticular Ultramicroporous Metal-Organic Frameworks. J. Am. Chem. Soc. 2018, 140, 12940-12946. [CrossRef] [PubMed]

16. Chen, Y.; Qiao, Z.; Wu, H.; Lv, D.; Shi, R.; Xia, Q.; Zhou, J.; Li, Z. An ethane-trapping MOF PCN-250 for highly selective adsorption of ethane over ethylene. Chem. Eng. Sci. 2018, 175, 110-117. [CrossRef]

17. Hao, H.-G.; Zhao, Y.-F.; Chen, D.-M.; Yu, J.-M.; Tan, K.; Ma, S.; Chabal, Y.; Zhang, Z.-M.; Dou, J.-M.; Xiao, Z.-H.; et al. Simultaneous Trapping of $\mathrm{C} 2 \mathrm{H} 2$ and $\mathrm{C} 2 \mathrm{H} 6$ from a Ternary Mixture of $\mathrm{C} 2 \mathrm{H} 2 / \mathrm{C} 2 \mathrm{H} 4 / \mathrm{C} 2 \mathrm{H} 6$ in a Robust Metal-Organic Framework for the Purification of C2H4. Angew. Chem. Int. Ed. 2018, 57, 16067-16071. [CrossRef]

18. Chen, K.-J.; Madden, D.G.; Mukherjee, S.; Pham, T.; Forrest, K.A.; Kumar, A.; Space, B.; Kong, J.; Zhang, Q.-Y.; Zaworotko, M.J. Synergistic sorbent separation for one-step ethylene purification from a four-component mixture. Science 2019, 366, 241-246. [CrossRef]

19. Haldoupis, E.; Nair, S.; Sholl, D.S. Finding MOFs for Highly Selective $\mathrm{CO}_{2} / \mathrm{N}_{2}$ Adsorption Using Materials Screening Based on Efficient Assignment of Atomic Point Charges. J. Am. Chem. Soc. 2012, 134, 4313-4323. [CrossRef]

20. Wilmer, C.E.; Leaf, M.; Lee, C.Y.; Farha, O.K.; Hauser, B.G.; Hupp, J.T.; Snurr, R.Q. Large-scale screening of hypothetical metal-organic frameworks. Nat. Chem. 2012, 4, 83-89. [CrossRef]

21. Qiao, Z.; Peng, C.; Zhou, J.; Jiang, J. High-throughput computational screening of 137953 metal-organic frameworks for membrane separation of a CO2/N2/CH4 mixture. J. Mater. Chem. A 2016, 4, 15904-15912. [CrossRef]

22. Wu, D.; Wang, C.; Liu, B.; Liu, D.; Yang, Q.; Zhong, C. Large-scale computational screening of metal-organic frameworks for CH4/H2 separation. AIChE J. 2012, 58, 2078-2084. [CrossRef]

23. Altintas, C.; Avci, G.; Daglar, H.; Gulcay, E.; Erucar, I.; Keskin, S. Computer simulations of $4240 \mathrm{MOF}$ membranes for H2/CH4 separations: Insights into structure-performance relations. J. Mater. Chem. A 2018, 6, 5836-5847. [CrossRef] [PubMed]

24. Nemati Vesali Azar, A.; Keskin, S. Computational Screening of MOFs for Acetylene Separation. Front. Chem. 2018, 6, 36. [CrossRef]

25. Altintas, C.; Keskin, S. Computational screening of MOFs for $\mathrm{C}_{2} \mathrm{H}_{6} / \mathrm{C}_{2} \mathrm{H}_{4}$ and $\mathrm{C}_{2} \mathrm{H}_{6} / \mathrm{CH}_{4}$ separations. Chem. Eng. Sci. 2016, 139, 49-60. [CrossRef]

26. Zhou, Y.; Zhou, T.; Sundmacher, K. In silico Screening of Metal-organic Frameworks for Acetylene/ethylene Separation. In Computer Aided Chemical Engineering; Pierucci, S., Manenti, F., Bozzano, G.L., Manca, D., Eds.; Elsevier: Amsterdam, The Netherlands, 2020; Volume 48, pp. 895-900.

27. Avci, G.; Velioglu, S.; Keskin, S. High-Throughput Screening of MOF Adsorbents and Membranes for H2 Purification and CO2 Capture. ACS Appl. Mater. Interfaces 2018, 10, 33693-33706. [CrossRef]

28. Yeo, B.C.; Kim, D.; Kim, H.; Han, S.S. High-Throughput Screening to Investigate the Relationship between the Selectivity and Working Capacity of Porous Materials for Propylene/Propane Adsorptive Separation. J. Phys. Chem. C 2016, 120, 24224-24230. [CrossRef]

29. Chung, Y.G.; Bai, P.; Haranczyk, M.; Leperi, K.T.; Li, P.; Zhang, H.; Wang, T.C.; Duerinck, T.; You, F.; Hupp, J.T.; et al. Computational Screening of Nanoporous Materials for Hexane and Heptane Isomer Separation. Chem. Mater. 2017, 29, 6315-6328. [CrossRef]

30. Qiao, Z.; Yan, Y.; Tang, Y.; Liang, H.; Jiang, J. Metal-Organic Frameworks for Xylene Separation: From Computational Screening to Machine Learning. J. Phys. Chem. C 2021, 125, 7839-7848. [CrossRef]

31. Farmahini, A.H.; Friedrich, D.; Brandani, S.; Sarkisov, L. Exploring new sources of efficiency in process-driven materials screening for post-combustion carbon capture. Energy Environ. Sci. 2020, 13, 1018-1037. [CrossRef]

32. Farmahini, A.H.; Krishnamurthy, S.; Friedrich, D.; Brandani, S.; Sarkisov, L. From Crystal to Adsorption Column: Challenges in Multiscale Computational Screening of Materials for Adsorption Separation Processes. Ind. Eng. Chem. Res. 2018, 57, 15491-15511. [CrossRef]

33. Chung, Y.G.; Camp, J.; Haranczyk, M.; Sikora, B.J.; Bury, W.; Krungleviciute, V.; Yildirim, T.; Farha, O.K.; Sholl, D.S.; Snurr, R.Q. Computation-Ready, Experimental Metal-Organic Frameworks: A Tool To Enable High-Throughput Screening of Nanoporous Crystals. Chem. Mater. 2014, 26, 6185-6192. [CrossRef] 
34. Groom, C.R.; Bruno, I.J.; Lightfoot, M.P.; Ward, S.C. The Cambridge structural database. Acta Crystallogr. Sect. B Struct. Sci. Cryst. Eng. Mater. 2016, 72, 171-179. [CrossRef] [PubMed]

35. Frenkel, D.; Smit, B. Understanding Molecular Simulation: From Algorithms to Applications; Elsevier: Amsterdam, The Netherlands, 2001; Volume 1.

36. Dubbeldam, D.; Calero, S.; Ellis, D.E.; Snurr, R.Q. RASPA: Molecular simulation software for adsorption and diffusion in flexible nanoporous materials. Mol. Simul. 2016, 42, 81-101. [CrossRef]

37. Qiao, Z.; Zhang, K.; Jiang, J. In silico screening of 4764 computation-ready, experimental metal-organic frameworks for $\mathrm{CO}_{2}$ separation. J. Mater. Chem. A 2016, 4, 2105-2114. [CrossRef]

38. Fischer, M.; Hoffmann, F.; Fröba, M. New Microporous Materials for Acetylene Storage and C2H2/CO2 Separation: Insights from Molecular Simulations. ChemPhysChem 2010, 11, 2220-2229. [CrossRef]

39. Liu, B.; Smit, B.; Rey, F.; Valencia, S.; Calero, S. A New United Atom Force Field for Adsorption of Alkenes in Zeolites. J. Phys. Chem. C 2008, 112, 2492-2498. [CrossRef]

40. Mayo, S.L.; Olafson, B.D.; Goddard, W.A. DREIDING: A generic force field for molecular simulations. J. Phys. Chem. 1990, 94, 8897-8909. [CrossRef]

41. Rappe, A.K.; Casewit, C.J.; Colwell, K.S.; Goddard, W.A.; Skiff, W.M. UFF, a full periodic table force field for molecular mechanics and molecular dynamics simulations. J. Am. Chem. Soc. 1992, 114, 10024-10035. [CrossRef]

42. Wilmer, C.E.; Kim, K.C.; Snurr, R.Q. An Extended Charge Equilibration Method. J. Phys. Chem. Lett. 2012, 3, 2506-2511. [CrossRef]

43. He, Y.; Krishna, R.; Chen, B. Metal-organic frameworks with potential for energy-efficient adsorptive separation of light hydrocarbons. Energy Environ. Sci. 2012, 5, 9107-9120. [CrossRef]

44. Xiang, S.; Zhou, W.; Gallegos, J.M.; Liu, Y.; Chen, B. Exceptionally High Acetylene Uptake in a Microporous Metal-Organic Framework with Open Metal Sites. J. Am. Chem. Soc. 2009, 131, 12415-12419. [CrossRef]

45. Queen, W.L.; Hudson, M.R.; Bloch, E.D.; Mason, J.A.; Gonzalez, M.I.; Lee, J.S.; Gygi, D.; Howe, J.D.; Lee, K.; Darwish, T.A.; et al. Comprehensive study of carbon dioxide adsorption in the metal-organic frameworks $\mathrm{M} 2$ (dobdc) $(\mathrm{M}=\mathrm{Mg}, \mathrm{Mn}, \mathrm{Fe}, \mathrm{Co}, \mathrm{Ni}, \mathrm{Cu}$, Zn). Chem. Sci. 2014, 5, 4569-4581. [CrossRef]

46. Borycz, J.; Lin, L.-C.; Bloch, E.D.; Kim, J.; Dzubak, A.L.; Maurice, R.; Semrouni, D.; Lee, K.; Smit, B.; Gagliardi, L. CO 2 Adsorption in Fe2(dobdc): A Classical Force Field Parameterized from Quantum Mechanical Calculations. J. Phys. Chem. C 2014, 118, 12230-12240. [CrossRef]

47. Haldoupis, E.; Borycz, J.; Shi, H.; Vogiatzis, K.D.; Bai, P.; Queen, W.L.; Gagliardi, L.; Siepmann, J.I. Ab Initio Derived Force Fields for Predicting $\mathrm{CO}_{2}$ Adsorption and Accessibility of Metal Sites in the Metal-Organic Frameworks M-MOF-74 (M = Mn, Co, Ni, Cu). J. Phys. Chem. C 2015, 119, 16058-16071. [CrossRef]

48. Kim, J.; Lin, L.-C.; Martin, R.L.; Swisher, J.A.; Haranczyk, M.; Smit, B. Large-Scale Computational Screening of Zeolites for Ethane/Ethene Separation. Langmuir 2012, 28, 11914-11919. [CrossRef]

49. Watanabe, T.; Sholl, D.S. Accelerating Applications of Metal-Organic Frameworks for Gas Adsorption and Separation by Computational Screening of Materials. Langmuir 2012, 28, 14114-14128. [CrossRef]

50. Kong, G.-Q.; Han, Z.-D.; He, Y.; Ou, S.; Zhou, W.; Yildirim, T.; Krishna, R.; Zou, C.; Chen, B.; Wu, C.-D. Expanded Organic Building Units for the Construction of Highly Porous Metal-Organic Frameworks. Chem. Eur. J. 2013, 19, 14886-14894. [CrossRef] [PubMed] 